\title{
Differential expression of $C X C R 1$ and commonly used reference genes in bovine milk somatic cells following experimental intramammary challenge
}

\author{
Joren Verbeke ${ }^{1 *}$, Mario Van Poucke ${ }^{2}$, Luc Peelman² and Sarne De Vliegher ${ }^{1}$
}

\begin{abstract}
Background: Chemokine (C-X-C motif) receptor 1 (CXCR1 or IL-8RA) plays an important role in the bovine mammary gland immunity. Previous research indicated polymorphism c.980A > G in the CXCR1 gene to influence milk neutrophils and mastitis resistance. In the present study, four c.980AG heifers and four c.980GG heifers were experimentally infected with Staphylococcus chromogenes. RNA was isolated from milk somatic cells one hour before and 12 hours after the experimental intramammary challenge. Expression of CXCR1 and eight candidate reference genes (ACTB, B2M, H2A, HPRT1, RPS15A, SDHA, UBC and YWHAZ) was measured by reverse transcription quantitative real-time PCR (RT-GPCR). Differences in relative CXCR1 expression between c.980AG heifers and c.980GG heifers were studied and the effect of the experimental intramammary challenge on relative expression of $C X C R 1$ and the candidate reference genes was analyzed.
\end{abstract}

Results: Relative expression of CXCR1 was not associated with polymorphism c.980A > G but was significantly upregulated following the experimental intramammary challenge. Additionally, differential expression was detected for B2M, H2A, HPRT1, SDHA and YWHAZ.

Conclusions: This study reinforces the importance of $C X C R 1$ in mammary gland immunity and demonstrates the potential effect of experimental intramammary challenge on expression of candidate reference genes in milk somatic cells.

Keywords: CXCR1, RT-qPCR, Milk somatic cell, Experimental intramammary challenge

\section{Background}

After invading the bovine mammary gland, pathogens can cause an intramammary infection (IMI) followed by an inflammatory response called mastitis. Neutrophils migrating from blood to milk play an important role in the mammary gland immunity [1]. Binding of cytokine interleukin-8 on chemokine (C-X-C motif) receptor 1 (CXCR1) causes chemotaxis and enhances viability of bovine neutrophils [2,3]. Despite its important function, many single nucleotide polymorphisms (SNP) were detected in the CXCR1 gene [4,5]. Recently, we reported a higher milk neutrophil viability and lower likelihood of IMI by major mastitis pathogens (e.g. Staphylococcus

\footnotetext{
* Correspondence: Joren.Verbeke@UGent.be

'M-team and Mastitis and Milk Quality Research Unit, Department of Reproduction, Obstetrics and Herd Health, Faculty of Veterinary Medicine, Ghent University, Salisburylaan 133, Merelbeke, Belgium

Full list of author information is available at the end of the article
}

aureus and Streptococcus uberis) in heifers with genotype CXCR1c.980AG compared to heifers with genotype CXCR1c.980GG $[4,6]$. Polymorphism c.980A > G causes the amino acid change p.Lys327Arg in the C-terminal region of the receptor potentially influencing interleukin 8 signal transduction. However, phenotypical differences could also be explained by linkage with SNPs in regulatory regions and an association between SNP c.980A > G and $C X C R 1$ gene expression. To test this hypothesis, we isolated RNA from milk somatic cells isolated before and after an experimental challenge with Staphylococcus chromogenes. Next, differences in CXCR1 expression between c.980AG and c.980GG heifers were studied using reverse transcription quantitative real-time PCR (RT-qPCR). Additionally, the influence of the experimental intramammary challenge on expression of CXCR1 and commonly used reference genes was analyzed. 


\section{Methods}

Test animals

This experiment has been approved by the ethical committee of the Faculty of Veterinary Medicine, Ghent University (EC2012/73). A blood sample was taken from all Holstein heifers $(n=20)$ of the commercial dairy herd of Ghent University (Biocenter Agri-Vet, Melle, Belgium). The whole coding region of CXCR1 was genotyped by direct sequencing as previously described [4]. Four heifers with genotype c.980AG and 4 heifers with genotype c.980GG were selected. Selected heifers were not siblings, had no history of clinical mastitis or other diseases, and were between 75 and 280 days in milk at the time of the experiment. Duplicate milk samples were taken four days and one hour before the experiment. Bacteriological culture was performed according to National Mastitis Council (NMC) guidelines [7]. All quarters of all heifers were culture-negative at that time. Quarter SCC was measured before and during the experiment in duplicate using a DeLaval cell counter (DCC, DeLaval International AB, Tumba, Sweden).

\section{Experimental challenge}

Data were available from a larger experimental infection study in which each heifer was inoculated briefly after the morning milking (8 a.m.) with two different strains of S. chromogenes, a strain of Staphylococcus fleurettii, and sterile phosphate buffered saline (PBS) in a splitudder design (one strain or PBS per individual quarter) to study differences in pathogenicity and immune response between coagulase-negative staphylococci. One $S$. chromogenes (S. chromogenes IM) strain originated from a chronically infected quarter [8] whereas the other $(S$. chromogenes TA) originated from the teat apex and was found to inhibit the growth of major pathogens in vitro [9]. The S. fleurettii strain originated from sawdust [8]. For each strain, $1 * 10^{6} \mathrm{CFU}$ in $5 \mathrm{~mL}$ PBS was inoculated using a sterile catheter (Vygon, Ecouen, France). The bacterial count was determined by incubating a tenfold serial dilution of a representative frozen aliquot $18 \mathrm{~h}$ before inoculation. Five $\mathrm{mL}$ of sterile PBS was inoculated in the fourth quarter (further referred to as neighboring quarters). For this research, additional milk samples of $600 \mathrm{~mL}$ were taken $1 \mathrm{~h}$ before and $12 \mathrm{~h}$ after inoculation from quarters (to be) inoculated with PBS or S. chromogenes IM (Figure 1). Cows were milked after sampling.

\section{Milk somatic cell isolation}

Samples were transported on ice to the laboratory where milk was divided equally between three 400-mL centrifuge bottles, diluted $50 \%(\mathrm{vol} / \mathrm{vol})$ with cold PBS, and centrifuged at $1500 \times \mathrm{g}$ for $15 \mathrm{~min}$ at $4^{\circ} \mathrm{C}$ in a fixed angle rotor. The supernatant was discarded. The three milk somatic cell pellets were resuspended in a total of $40 \mathrm{~mL}$
PBS, divided between two 50-mL Falcon tubes and washed three times with $10 \mathrm{~mL}$ cold PBS (centrifugation at $200 \mathrm{x} \mathrm{g}$ for $10 \mathrm{~min}$ at $4^{\circ} \mathrm{C}$ ). The final milk somatic cell pellets were suspended in $1 \mathrm{~mL}$ of RPMI 1640 (Gibco Brl., Scotland, UK) supplemented with 1\% BSA (Merck KGaA, Darmstadt, Germany). Twenty $\mu \mathrm{L}$ of the suspension was diluted with $380 \mu$ low SCC milk (SCC < 50 cells $/ \mathrm{mL}$ ) and measured with a DeLaval cell counter to estimate the cell concentration using following formula; SCCsample (in cells $/ \mu \mathrm{l})=\frac{400 * \mathrm{SCC}_{\text {mix }}-380 * \mathrm{SCC}_{\text {milk }}}{20}$. Approximately $5 * 10^{6}$ cells were pipetted in a $2 \mathrm{~mL}$ test tube, pelleted by centrifugation at $16,100 \mathrm{x}$ g for $1 \mathrm{~min}$ at $4^{\circ} \mathrm{C}$ and resuspended in $1 \mathrm{~mL}$ TRI Reagent Solution (Ambion, Austin, TX). If less cells were available, all of the cell suspension was used. Samples were frozen and stored at $-20^{\circ} \mathrm{C}$ for $8-10$ months.

\section{RNA extraction and CDNA synthesis}

RNA was isolated following the manufacturer's instructions of TRI Reagent Solution (Ambion, Austin, TX). Genomic DNA was removed by adding $4 \mu \mathrm{L}$ RQ1 DNase (0.5 U/ $\mu \mathrm{L}$, Promega, Leiden, Netherlands) and $2.7 \mu \mathrm{L}$ RQ1 DNase 10X Reaction Buffer (Promega) followed by incubation for $30 \mathrm{~min}$ at $37^{\circ} \mathrm{C}$. The reaction was terminated by adding $3 \mu \mathrm{L}$ RQ1 DNase Stop Solution (Promega) followed by incubation for $10 \mathrm{~min}$ at $65^{\circ} \mathrm{C}$. The RNA was purified by spin-column centrifugation (Amicon Ultra-0.5 centrifugal filter device, Merck Millipore, Billerica, MA) to approximately $15 \mu \mathrm{L}$. Its concentration and purity was estimated using a ND-1000 spectrophotometer (NanoDrop, Wilmington, NC). RNA degradation was analyzed by gel electrophoresis of a representative sample. Due to low yield in many samples, an additional PCR assay was designed to analyze cDNA integrity of all samples (see further).

DNA contamination was assessed by performing a minus RT control. A PCR mix, in a total volume of $10 \mu \mathrm{L}$, containing $0.4 \mu \mathrm{L}$ sample (double the equivalent of RNA input in the qPCR reaction), $1 \mu \mathrm{L} 10 \times$ FastStart Taq DNA Polymerase Buffer (Roche Applied Science), $0.2 \mu \mathrm{l}$ dNTP Mix (10 mM each; BIOLINE, London, UK), $0.5 \mu \mathrm{L}$ forward primer [YWHAZ + 1, $5 \mu \mathrm{M}, 5$-GCATCC CACAGACTATTTCC-3', IDT (Integrated DNA Technologies), Leuven, Belgium], $0.5 \mu \mathrm{L}$ reverse primer (YWHAZ-1, $5 \mu \mathrm{M}$, 5'-GCAAAGACAATGACAGACCA-3', IDT) and $0.1 \mu \mathrm{L}$ Taq DNA Polymerase (5 U/ $\mu$, Roche Applied Science) was made. The PCR program consisted of an initiation step of $4 \mathrm{~min}$ at $95^{\circ} \mathrm{C}$ followed by 40 amplification cycles (denaturation for $10 \mathrm{~s}$ at $95^{\circ} \mathrm{C}$, annealing for $10 \mathrm{~s}$ at $58^{\circ} \mathrm{C}$ and extension for $20 \mathrm{~s}$ at $72^{\circ} \mathrm{C}$ ) and a final 2-min elongation step at $72^{\circ} \mathrm{C}$. DNA amplification (120 bp) was examined by electrophoresis on ethidium bromidestained agarose (2\%) gel $(150 \mathrm{~V}, 20 \mathrm{~min})$. 


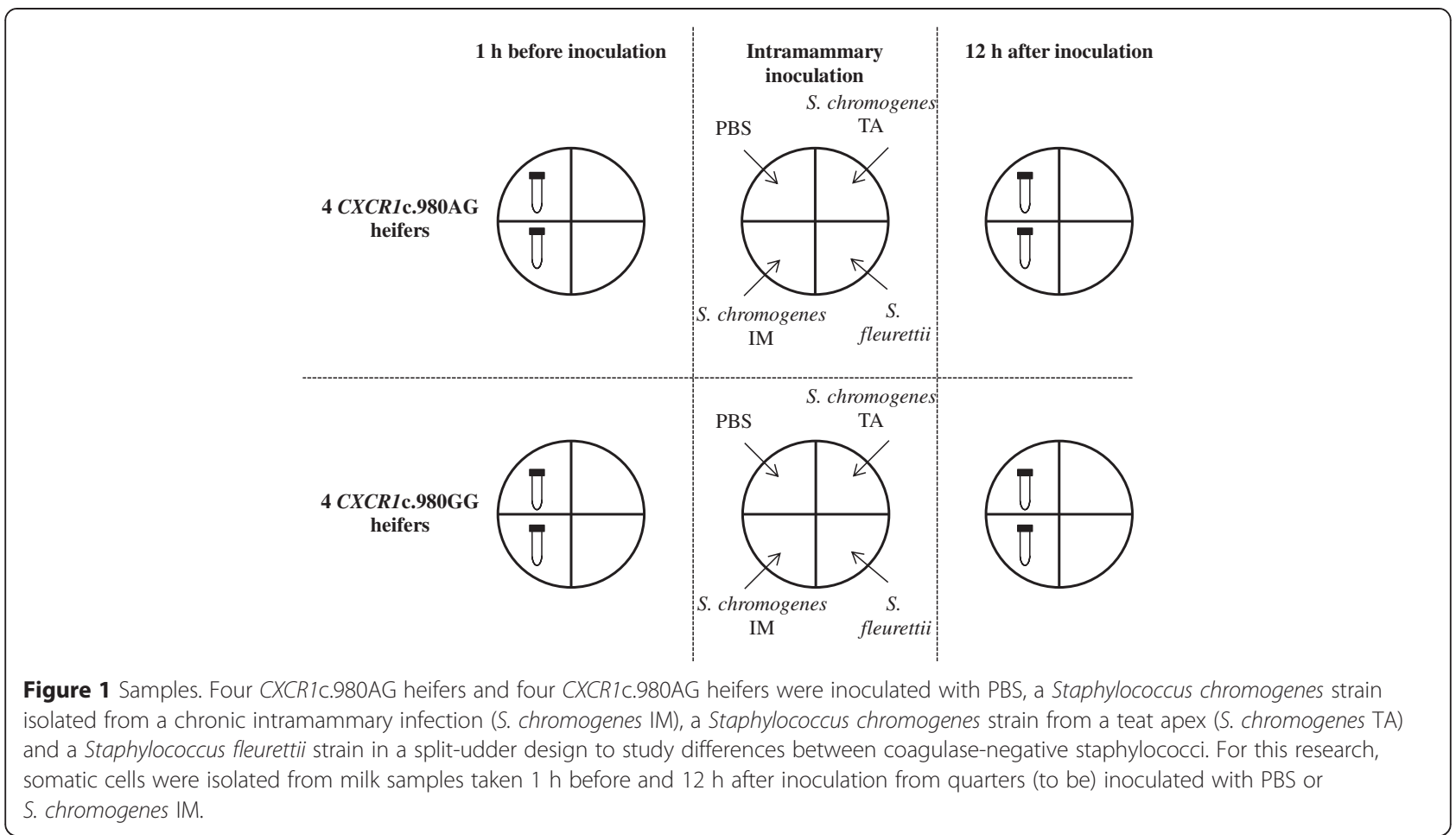

Improm-II reverse transcriptase (Promega) was used to convert DNA-free RNA into cDNA. First, $10 \mu \mathrm{L}$ sample containing a maximum of $1 \mu \mathrm{g}$ RNA was mixed with $0.8 \mu \mathrm{L}$ random hexamer primers $(10 \mu \mathrm{M}$, IDT $)$ and $0.8 \mu \mathrm{L}$ oligo $(\mathrm{dT})_{15}$ primer $(10 \mu \mathrm{M}$, IDT). If less than $1 \mu \mathrm{g}$ RNA was extracted, all available RNA was used. The primer/template mix was thermally denatured by $5 \mathrm{~min}$ incubation at $70^{\circ} \mathrm{C}$ followed by $5 \mathrm{~min}$ incubation on ice. Secondly, $4 \mu \mathrm{L}$ Improm-II $5 x$ reaction buffer, $2.4 \mu \mathrm{L} \mathrm{MgCl}_{2}(25 \mathrm{mM}), 1 \mu \mathrm{L}$ dNTP Mix $(10 \mathrm{mM}$ each; BIOLINE) and $1 \mu \mathrm{L}$ Improm-II reverse transcriptase (20 $\mathrm{U} / \mu \mathrm{L}$ ) was added. The final volume of $20 \mu \mathrm{L}$ was incubated $5 \mathrm{~min}$ at $25^{\circ} \mathrm{C}$ (primer annealing), $60 \mathrm{~min}$ at $42^{\circ} \mathrm{C}$ (first-strand synthesis reaction), and $15 \mathrm{~min}$ at $70^{\circ} \mathrm{C}$ (inactivation of reverse transcriptase). Samples were 5 times diluted and stored at $-20^{\circ} \mathrm{C}$.

\section{PCR assay to assess cDNA integrity}

Complementary DNA integrity was assessed using two 4-primer PCR assays multiplying fragments of approximately 100, 500 and 900 bps of YWHAZ and CXCR1, respectively. For both assays, a forward and 3 reverse PCR primers were designed using Primer3Plus [10] and synthesized by IDT. Sequences are shown in Table 1. Regions forming potential secondary structures were identified with Mfold [11] and avoided. Specificity of binding of the primers was analyzed using NCBI BLAST [12]. For both assays, a PCR mix, in a total volume of $10 \mu \mathrm{L}$, containing $2 \mu \mathrm{L} 5 \mathrm{x}$ diluted cDNA, $1.0 \mu \mathrm{L} 10 \times$ FastStart
Taq DNA Polymerase Buffer (Roche Applied Science), $0.3 \mu \mathrm{L}$ dNTP Mix (10 mM each; BIOLINE), $1 \mu \mathrm{L}$ forward primer $(5 \mu \mathrm{M}), 0.3 \mu \mathrm{L}$ reverse primer $1(5 \mu \mathrm{M})$, $0.3 \mu \mathrm{L}$ reverse primer $2(5 \mu \mathrm{M}), 0.6 \mu \mathrm{L}$ reverse primer 3 $(5 \mu \mathrm{M})$ and $0.1 \mu \mathrm{L}$ Taq DNA Polymerase $(5 \mathrm{U} / \mu \mathrm{l}$, Roche Applied Science) was made. The PCR program consisted of an initiation step of $4 \mathrm{~min}$ at $95^{\circ} \mathrm{C}$ followed by 40 amplification cycles (denaturation for $45 \mathrm{~s}$ at $95^{\circ} \mathrm{C}$, annealing for $45 \mathrm{~s}$ at the optimal annealing temperature and extension for $1 \mathrm{~min} 30 \mathrm{~s}$ at $72^{\circ} \mathrm{C}$ ) and a final 4-min elongation step at $72^{\circ} \mathrm{C}$. The optimal annealing temperature for the $Y W H A Z$ and $C X C R 1$ assay $\left(60^{\circ} \mathrm{C}\right.$ and $65^{\circ} \mathrm{C}$, respectively)

Table 1 Primers used in two PCR assays multiplying three fragments of YWHAZ and CXCR1, respectively

\begin{tabular}{llll}
\hline Gene & Primer & Sequence $\left(\mathbf{5}^{\prime} \rightarrow \mathbf{3}^{\prime}\right)$ & $\begin{array}{l}\text { Product } \\
\text { size }\end{array}$ \\
\hline YWHAZ $^{a}$ & Forward & GAGCAAAAGACGGAAGGTGCT & \\
& Reverse 1 & CCAAAAGAGACAGTACATCATTGCA & 109 \\
& Reverse 2 & TCCGATGTCCACAATGTCAAGT & 497 \\
& Reverse 3 & TCCCCACCAGGACATACCAA & 909 \\
$C X C R 7^{b}$ & Forward & TCCCTGTGAGATAAGCACTGAGACA & \\
& Reverse 1 & AGCGACCAATCCGGCTGTA & 131 \\
& Reverse 2 & CGTTGATTGGCACCCAGGTC & 505 \\
& Reverse 3 & GTCCGTGGCGAACTTCTGG & 863 \\
\hline
\end{tabular}

aTyrosine 3-monooxygenase/tryptophan 5-monooxygenase activation protein, zeta polypeptide [NM_174814.2].

${ }^{\mathrm{b}}$ Chemokine (C-X-C motif) receptor 1 [NM_174360.2]. 
were determined experimentally. Complementary DNA amplification was examined by electrophoresis on ethidium bromide-stained agarose $(0.8 \%)$ gel $(150 \mathrm{~V}, 25 \mathrm{~min})$. The cDNA integrity was considered excellent, sufficient or insufficient if, respectively, 3, 2 or 1 bands were visible in both assays (Figure 2).

\section{RT-qPCR}

Ten candidate reference genes were selected based upon previous research [13-15]: ACTB, B2M, H2A, HPRT1, PPP1R11, RPS15A, SDHA, TBP, UBC, and YWHAZ. Primers were ordered from IDT. Gene, primer and amplicon information is listed in Table 2. A PCR mix of $10 \mu \mathrm{L}$ containing $5 \mu \mathrm{L} 2 \mathrm{x}$ SYBR Green I Master Mix (Roche Diagnostics, Basel, Switzerland), $1 \mu \mathrm{L}$ forward primer $(5 \mu \mathrm{M}), 1 \mu \mathrm{L}$ reverse primer $(5 \mu \mathrm{M})$ and $2 \mu \mathrm{L}$ cDNA sample was made. The PCR program consisted of an initiation step of $3 \mathrm{~min}$ at $95^{\circ} \mathrm{C}$, followed by 40 amplification cycles (denaturation for $30 \mathrm{~s}$ at $95^{\circ} \mathrm{C}$, annealing-elongation for $40 \mathrm{~s}$ at the optimal annealing temperature and detection of fluorescent signals generated by SYBR Green I binding to dsDNA). Samples were heated from $75^{\circ} \mathrm{C}$ to $95^{\circ} \mathrm{C}$ in $0.5^{\circ} \mathrm{C}$ increments per $5 \mathrm{~s}$ while continuously measuring fluorescence. The generated melt curve was used to confirm a single gene-specific peak and to detect primer/dimer formation. Optimal annealing temperatures were determined experimentally by gradient qPCR on a 4-fold serial dilution until $1 / 1024$ of pooled cDNA of all samples. All reactions were performed in duplicate. In each run, the serial dilution and a no template control were included to analyze calibration curves, PCR efficiency (E) and squared correlation coefficient $\left(\mathrm{r}^{2}\right)$ and check for PCR contamination. All qPCRs were performed in PCR strips (Bio-Rad, Hercules, CA) using a CFX96 Touch ${ }^{\text {mo }}$ Real-Time PCR Detection System (Bio-Rad). Quantification cycles (Cqs) were analyzed with CFX Manager ${ }^{\mathrm{rm}}$ Software v3.1 (Bio-Rad). The raw $\mathrm{Cq}$ values were converted to quantiles $(\mathrm{Q})$ using following formula; $\mathrm{Q}=(1+\mathrm{E})^{(\mathrm{CqS}-\mathrm{CqL})}$ with $\mathrm{E}=\mathrm{PCR}$ efficiency, $\mathrm{CqS}=\mathrm{Cq}$ value of the sample and $\mathrm{CqL}=$ lowest $\mathrm{Cq}$ value of all samples.

\section{Analysis of gene expression stability}

Stability of the different candidate reference genes were analyzed using Normfinder (version 0.953, [16]) Excel Add-In. Samples were grouped as (1) all samples $1 \mathrm{~h}$ before inoculation, (2) samples from quarters inoculated with PBS $12 \mathrm{~h}$ after inoculation, and (3) samples from quarters inoculated with $S$. chromogenes IM $12 \mathrm{~h}$ after inoculation. Normfinder estimates an expression stability measure $(\rho)$ per candidate reference gene based on the overall variation of the expression and the variation of the expression between the subgroups [16].

\section{Data analysis}

Differences in gene expression between CXCR1 genotype and sample subgroups were further studied using SAS 9.4 (SAS Institute Inc., NC, USA). First, expression of B2M, CXCR1, H2A, HPRT1, SDHA and YWHAZ were normalized by the geometric mean of the three most stable genes (ACTB, RPS15A and $U B C$; see further). Expression of $A C T B, R P S 15 A$ and $U B C$ were normalized to the geometric mean of the other two most stable genes.

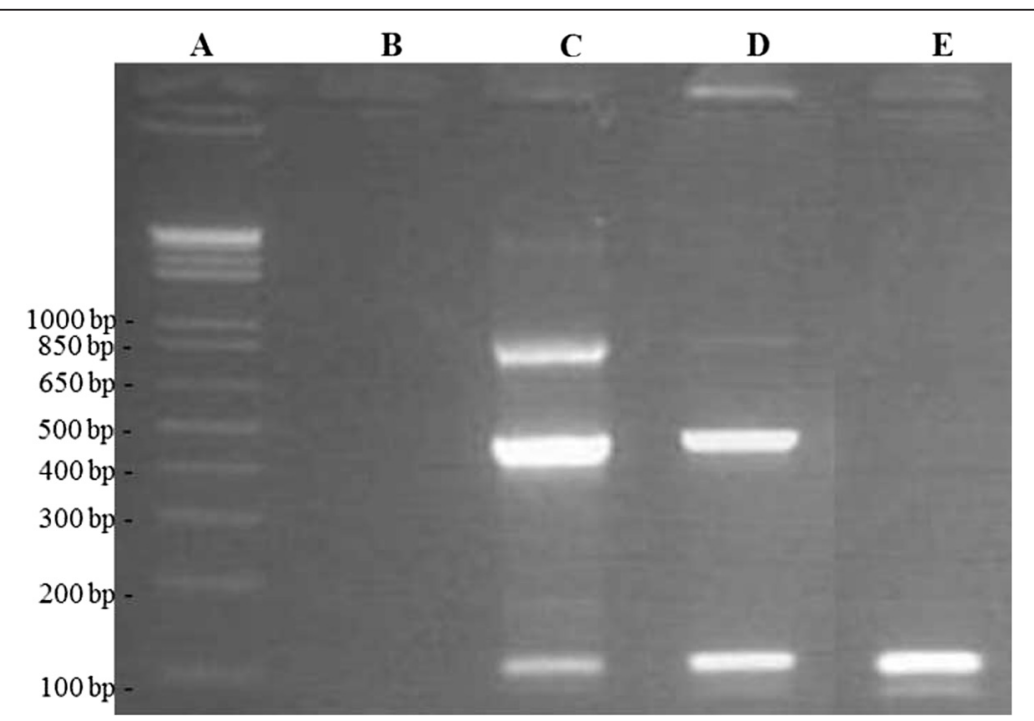

Figure 2 Agarose gel of a PCR assay with 4 YWHAZ primer used to assess cDNA integrity. Lane A) Marker (1-kb + DNA Ladder, Promega, Madison, Wl); lane B) No template control; lane C) cDNA sample with amplified fragments of approximately 100, 500 and 900 bps (excellent integrity); lane D) CDNA sample with amplified fragments of approximately 100 and 900 bps (sufficient integrity) and lane E) cDNA sample with amplified fragment of approximately 100 bps (insufficient integrity). 
Table 2 Gene, primer and amplicon information

\begin{tabular}{|c|c|c|c|c|c|c|c|}
\hline Gene full name & NCBI Gene ID & $\begin{array}{l}\text { Genbank Accession } \\
\text { number }\end{array}$ & & Sequence $\left(5^{\prime} \rightarrow 3^{\prime}\right)$ & $\begin{array}{l}\text { Genomic } \\
\text { location }\end{array}$ & $\begin{array}{l}\text { Product } \\
\text { size (bp) }\end{array}$ & $\mathrm{Ta}\left({ }^{\circ} \mathrm{C}\right)$ \\
\hline ACTB & 280979 & NM_173979.3 & $\mathrm{F}^{\mathrm{a}}$ & CCTCACGGAACGTGGTTACA & $\mathrm{CDS}^{\mathrm{b}}$ & 87 & 58 \\
\hline Actin, beta & & & $R^{a}$ & TCCTTGATGTCACGCACAATTT & CDS & & \\
\hline$B 2 M$ & 280729 & NM_173893.3 & $\mathrm{F}$ & AGACACCCACCAGAAGATGG & CDS & 206 & 59 \\
\hline \multicolumn{3}{|c|}{ Beta-2-microglobulin } & R & CGGCAGCTGTACTGATCCTT & CDS & & \\
\hline$C X C R 1$ & 281863 & NM_174360.2 & $\mathrm{F}$ & TCCCTGTGAGATAAGCACTGAGACAC & CDS & 118 & 64 \\
\hline \multicolumn{3}{|c|}{ Chemokine (C-X-C motif) receptor 1} & R & GCTGTATAAGATGACCAGCATCACCA & CDS & & \\
\hline$H 2 A$ & 506900 & NM_001205596.1 & $\mathrm{F}$ & GTCGTGGCAAGCAAGGAG & CDS & 182 & 60 \\
\hline \multicolumn{3}{|l|}{ Histone 2 alpha } & R & GATCTCGGCCGTTAGGTACTC & CDS & & \\
\hline HPRT1 & 281229 & NM_001034035.2 & $\mathrm{F}$ & TGCTGAGGATTGGAGAAGG & CDS & 154 & 58 \\
\hline \multicolumn{3}{|c|}{ Hypoxanthine phosphoribosyl-transferase I } & $\mathrm{R}$ & CAACAGGTCGGCAAAGAACT & CDS & & \\
\hline PPPIR11 & 504846 & NM_001100295.1 & $\mathrm{F}$ & ACCATCAAACTTCGGAAACG & CDS & 166 & 57 \\
\hline \multicolumn{3}{|c|}{ Protein phosphatase 1, regulatory (inhibitor) subunit 11} & $\mathrm{R}$ & ССTCCTCTTCCTCGTCATCA & CDS & & \\
\hline RPS15A & 337888 & NM_001037443.2 & $\mathrm{F}$ & AATGTCCTGGCTGATGCTCT & CDS & 218 & 59 \\
\hline \multicolumn{3}{|c|}{ Ribosomal protein S15a } & $\mathrm{R}$ & GGGCTGATCACTCCACACTT & CDS & & \\
\hline SDHA & 281480 & NM_174178.2 & $\mathrm{F}$ & GCAGAACCTGATGCTITGTG & CDS & 185 & 60 \\
\hline \multicolumn{3}{|c|}{ Succinate dehydrogenase flavoprotein subunit A } & $\mathrm{R}$ & CGTAGGAGAGCGTGTGCTT & CDS & & \\
\hline$T B P^{5}$ & 516578 & NM_001075742.1 & $\mathrm{F}$ & AATGGCTGCTGTGTTCTCCT & $3^{\prime} U_{T R}^{C}$ & 214 & 60 \\
\hline \multicolumn{3}{|c|}{ TATA box binding protein } & $\mathrm{R}$ & TGACGCTCTGGTGTTCTCTGT & $3^{\prime} U T R$ & & \\
\hline$U B C$ & 444874 & NM_001206307.1 & $\mathrm{F}$ & AGTTCAGTCTTCGTTCTTCTGTG & $5^{\prime} \cup T R^{d}$ & 88 & 58 \\
\hline \multicolumn{3}{|l|}{ Ubiquitin C } & R & GGTTTACCAGTGAGGGTCTT & CDS & & \\
\hline YWHAZ & 287022 & NM_174814.2 & $\mathrm{F}$ & GCATCCCACAGACTATTTCC & CDS & 120 & 60 \\
\hline \multicolumn{3}{|c|}{$\begin{array}{l}\text { Tyrosine 3-monooxygenase/tryptophan 5-monooxygenase } \\
\text { activation protein, zeta polypeptide }\end{array}$} & $\mathrm{R}$ & GCAAAGACAATGACAGACCA & CDS & & \\
\hline
\end{tabular}

Data were log transformed to obtain a normalized distribution. Secondly, a linear mixed regression model was fit with relative expression as outcome variable and heifer and quarter as random effect to correct for clustering of quarters within cows and two observations per quarter, respectively (PROC MIXED, SAS 9.4). Sample subgroup (1, 2 and 3) was added as fixed effect. In the model for CXCR1, genotype (c.980AG and c.980GG) and the interaction between sample subgroup and genotype were also tested. Statistical significance was assessed at $P \leq 0.05$.

\section{Results}

\section{Experimental challenge}

All milk samples taken 24, 12 and $1 \mathrm{~h}$ before experimental inoculation were culture negative. Quarters $(n=16)$ had a geometric mean SCC of 48,000 cells $/ \mathrm{ml}$ [Interquartile range (IQR) 26,000 - 84,000] $1 \mathrm{~h}$ before inoculation. Neighboring quarters remained culture negative after inoculation. Quarters inoculated with the S. chromogenes
IM developed subclinical mastitis as no local or systemic signs were observed and the challenge isolate was recovered from all quarters $6 \mathrm{~h}$ after inoculation. Twelve hours after inoculation, neighboring and infected quarters had a geometric mean SCC of 77,000 cells/ml (IQR 44,000 to 126,000 ) and $1,692,000$ cells/ml (IQR 861,000 to $3,371,000)$, respectively.

\section{Quality control of nucleic acids}

Total amount of isolated RNA ranged from $27.6 \mathrm{ng}$ to $36.5 \mu \mathrm{g}$ per sample. An average $\mathrm{A}_{260} / \mathrm{A}_{280}$ ratio of 2.04 was measured (range: 1.81-2.23). Gel electrophoresis of a representative sample indicated high quality rRNA. Additionally, the cDNA integrity was assessed using two four-primer PCR assays amplifying three different YWHAZ fragments and three different CXCR1 fragments. In two samples, gel electrophoresis of both assays showed no or only one band indicating cDNA integrity to be too low to amplify the medium and large fragments. Latter samples were not further analyzed. The cDNA integrity of the 
Table 3 qPCR information

\begin{tabular}{|c|c|c|c|c|c|c|}
\hline \multirow[t]{2}{*}{ Gene } & \multirow{2}{*}{$\begin{array}{l}\text { Median } \\
\mathrm{Cq}^{\mathrm{a}}\end{array}$} & \multirow{2}{*}{$\begin{array}{l}S D \\
\mathrm{Cq}^{\mathrm{b}}\end{array}$} & \multicolumn{4}{|c|}{ Calibration curve $^{c}$} \\
\hline & & & slope & $y$ intercept & $E(\%)$ & $r^{2}$ \\
\hline ACTB & 22.5 & 0.125 & -3.541 & 18.607 & 91.6 & 0.997 \\
\hline$B 2 M$ & 17.7 & 0.137 & -3.426 & 13.756 & 95.8 & 0.998 \\
\hline CXCR1 & 24.3 & 0.077 & -3.195 & 17.240 & 105.6 & 0.999 \\
\hline$H 2 A$ & 23.1 & 0.186 & -3.370 & 19.463 & 98.0 & 0.996 \\
\hline HPRT1 & 25.4 & 0.140 & -3.463 & 20.475 & 94.4 & 0.997 \\
\hline RPS15A & 19.3 & 0.151 & -3.433 & 15.213 & 95.6 & 0.999 \\
\hline SDHA & 23.4 & 0.148 & -3.534 & 19.385 & 91.8 & 0.999 \\
\hline$U B C$ & 22.5 & 0.122 & -3.248 & 18.150 & 103.2 & 0.998 \\
\hline YWHAZ & 22.8 & 0.097 & -3.368 & 19.139 & 98.1 & 0.999 \\
\hline
\end{tabular}

${ }^{a}$ Median of the quantification cycle (Cq) of all samples.

${ }^{b}$ Average standard deviation of the $\mathrm{Cq}$ values of replicate samples.

'Slope, y intercept, PCR efficiency and correlation coefficient estimated by qPCR on a 4-fold serial dilution of pooled cDNA of all samples.

remaining samples was considered sufficient (2 bands, $\mathrm{n}=8$ ) or excellent ( 3 bands, $\mathrm{n}=22$ ). Results of the YWHAZ and $C X C R 1$ assay were concordant.

\section{RT-qPCR and gene expression stability}

The gradient qPCR of PPP1R11 and TBP on the $1 / 1024$ dilution of the pooled cDNA showed weak fluorescent signals and melt peaks indicating low expression of these genes in the samples. They were not further tested as reference genes. The calibration curves of the remaining candidate reference genes and CXCR1 demonstrated PCR efficiencies close to $100 \%$ and correlation coefficients close to 1 indicating good assay performance. Median $\mathrm{Cq}$ values were low. The SD of the $\mathrm{Cq}$ values of replicate samples were limited demonstrating good repeatability (Table 3 ). Normfinder identified $U B C, R P S 15 A$ and $A C T B$ as the most stable genes based on their low inter- and intragroup variation in expression (Figure 3).

\section{Effect of genotype and experimental challenge on gene expression}

Genotype and the interaction between genotype and sample subgroup were non-significant $(P=0.55$ and 0.26 , respectively) and removed from the model for relative expression of CXCR1. Relative expression of CXCR1 was significantly higher in milk somatic cells from the infected and neighboring quarters $12 \mathrm{~h}$ after inoculation compared to milk somatic cells isolated $1 \mathrm{~h}$ before inoculation (both $P<0.01)$. Additionally, relative expression of $B 2 M, H 2 A$, HPRT1, SDHA and YWHAZ differed significantly between milk somatic cells from the infected quarters $12 \mathrm{~h}$ after inoculation and milk somatic cells isolated $1 \mathrm{~h}$ before inoculation $(P<0.05)$. Furthermore, relative expression of $B 2 M$ and $Y W H A Z$ differed significantly between milk somatic cells from the neighboring quarters $12 \mathrm{~h}$ after inoculation and milk somatic cells isolated $1 \mathrm{~h}$ before inoculation. Relative expression of the three most stable genes ( $A C T B$, $R P S 15 A$ and $U B C$ ) did not differ significantly between the subgroups (Table 4).

\section{Discussion}

Gene expression analysis in experimentally infected and healthy quarters allows for identification of differentially expressed genes and pathways. Quantitative real-time PCR in milk somatic cells isolated prior to inoculation and at different stages of experimental infection enables a detailed follow-up of the host response. In this study, we analyzed associations between SNP CXCR1c.980A > G and CXCR1 expression in milk somatic cells and studied the influence of an experimental intramammary challenge with

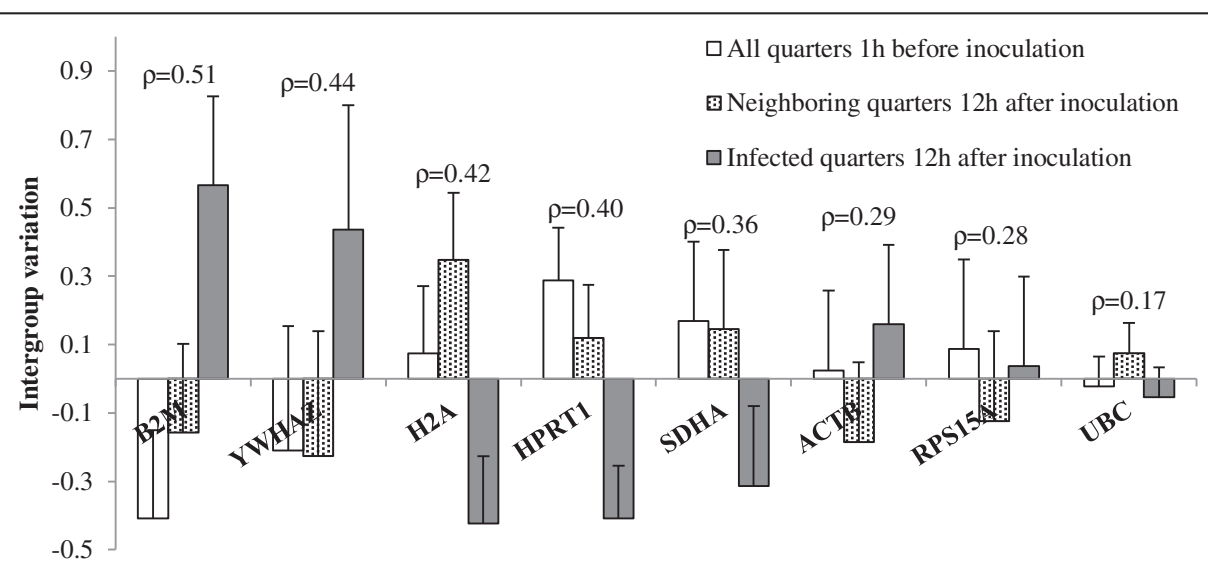

Figure 3 Gene expression stability of candidate reference genes in milk somatic cells analysed using Normfinder software. Intergroup variation (+ intragroup variation) of expression of 8 candidate reference genes in milk somatic cells isolated from quarters inoculated with PBS ( $\mathrm{n}=8$ ) or Staphylococcus chromogenes $(n=8)$ of 8 dairy heifers. Candidate reference genes are ranked on gene expression stability ( $\rho$ ) calculated using Normfinder [16] with most stable genes on the right side (smallest inter- and intragroup variation). 
Table 4 Linear mixed models describing the difference in gene expression in milk somatic cells before and after experimental challenge

\begin{tabular}{|c|c|c|c|c|c|c|c|c|}
\hline \multirow[t]{2}{*}{ Gene } & \multicolumn{2}{|c|}{$\begin{array}{l}\text { All quarters } 1 \mathrm{~h} \\
\text { before inoculation }^{\mathrm{a}} \\
\left(\mathrm{n}=15^{\mathrm{b}}\right)\end{array}$} & \multicolumn{3}{|c|}{$\begin{array}{l}\text { Neighboring quarters } \\
12 \mathrm{~h} \text { after inoculation } \\
(\mathrm{n}=8)\end{array}$} & \multicolumn{3}{|c|}{$\begin{array}{l}\text { Infected quarters } \\
12 \mathrm{~h} \text { after inoculation } \\
\left(\mathrm{n}=7^{\mathrm{b}}\right)\end{array}$} \\
\hline & $\beta_{0}^{c}$ & $\mathrm{SE}^{\mathrm{d}}$ & $\beta^{c}$ & $\mathrm{SE}^{\mathrm{d}}$ & $P$-value & $\beta^{c}$ & $\mathrm{SE}^{\mathrm{d}}$ & $P$-value \\
\hline ACTB & 0.27 & 0.07 & -0.06 & 0.08 & 0.46 & 0.10 & 0.09 & 0.27 \\
\hline$B 2 M$ & 0.04 & 0.06 & 0.15 & 0.07 & $<0.05$ & 0.41 & 0.07 & $<0.01$ \\
\hline CXCR1 & -1.30 & 0.15 & 0.94 & 0.26 & $<0.01$ & 1.71 & 0.27 & $<0.01$ \\
\hline$H 2 A$ & -0.04 & 0.06 & 0.17 & 0.07 & $<0.05$ & -0.21 & 0.07 & $<0.01$ \\
\hline HPRT1 & -0.08 & 0.05 & -0.03 & 0.07 & 0.66 & -0.31 & 0.07 & $<0.01$ \\
\hline RPS15A & -0.10 & 0.10 & -0.07 & 0.12 & 0.59 & -0.06 & 0.13 & 0.62 \\
\hline SDHA & -0.13 & 0.05 & 0.04 & 0.08 & 0.67 & -0.22 & 0.09 & $<0.05$ \\
\hline$U B C$ & -0.17 & 0.05 & 0.13 & 0.08 & 0.10 & -0.03 & 0.08 & 0.67 \\
\hline YWHAZ & -0.13 & 0.08 & 0.05 & 0.09 & 0.61 & 0.28 & 0.09 & $<0.01$ \\
\hline
\end{tabular}

${ }^{a}$ Two quarters of 8 dairy heifers were inoculated with PBS or Staphylococcus chromogenes.

${ }^{\mathrm{b}}$ Two samples showed insufficient cDNA integrity and were therefore removed from the dataset.

${ }^{\mathrm{C}}$ Regression coefficient.

${ }^{\mathrm{d}}$ Standard error.

Heifer and quarter were added as random effect to correct for clustering of quarters within cows and two observations per quarter, respectively.

S. chromogenes on expression of CXCR1 and eight commonly used reference genes. Because IMI in one quarter can influence gene expression and immunity in neighboring quarters $[17,18]$, we compared values before and after challenge rather than infected and non-infected quarters.

Compared to biopsies, milk somatic cells allow for easy resampling but yield less RNA, especially if the SCC is low [19]. Because of the low yield in some samples, we opted to isolate RNA from all milk somatic cells rather than a subpopulation (e.g. neutrophils). RNA integrity can influence RT-qPCR results but is not easy to asses [20]. Besides analyzing rRNA integrity of a representative sample using gel electrophoresis, we designed two four-primer PCR assays amplifying three fragments of YWHAZ and CXCR1 to test cDNA integrity of all samples. The assays are based on the fact that if integrity is too low, amplification of large fragments of approximately 500 and 900 bp will be affected. Latter fragments are more than 4 times as long as the amplicon of the target gene in the qPCR (118 bp).

Polymorphism c.980A > G was not associated with CXCR1 expression in milk somatic cells. Yet, relative CXCR1 expression increased in milk somatic cells isolated from infected quarters which corresponds well with in vitro research showing increased CXCR1 expression in blood neutrophils after in vitro LPS challenge [21]. To a lesser extent, transcription also increased in milk somatic cells from neighboring quarters. This might be due to cross-talk with the infected quarters or due to the inoculation of PBS. Although SCC increased little in the neighboring quarters, we cannot exclude a minimal inflammation caused by the insertion of the catheter, the PBS or both. The much higher increase in SCC and CXCR1 expression in the infected compared to the neighboring quarters suggests inflammation in the infected quarters to be mainly due to experimental IMI.

The experimental challenge had a significant effect on the relative expression of 5 out of 8 candidate reference genes. Important to mention is that candidate reference genes were selected based on a stable expression in other studies [13-15]. Reference genes in experimental infection studies should be stably expressed and unaffected by IMI. Validation of the reference gene to normalize gene expression data is not always published [20]. Although normalization to a single reference gene can cause relative large errors [22], it is often practiced $[17,23]$. If the expression of this single reference gene is affected by IMI, certain genes might be falsely identified as up- or downregulated whereas truly up- or downregulated genes might be missed.

\section{Conclusion}

In conclusion, CXCR1 expression in milk somatic cells was not associated with SNP c.980A > G but was upregulated following experimental IMI with $S$. chromogenes. Additionally, differential expression was observed for candidate fererence genes $B 2 M, H 2 A, H P R T 1, S D H A$ and $Y W H A Z$. The effect of intramammary challenge on expression of reference genes should be tested and reported in future studies on gene expression in milk somatic cells.

Competing interests

The authors declare that they have no competing interests.

Authors' contributions

JV and SDV designed the experiment. JV and MVP optimized all protocols. JV collected milk samples, extracted RNA, performed the qPCR and analyzed data 
with help of MVP. JV drafted the manuscript. MVP, LP and SDV gave critical comments on the manuscript. All authors read and approved the final manuscript.

\section{Acknowledgements}

This research was financed by a PhD grant ( $n^{\circ}$ 101206) by the Agency for Innovation by Science and Technology in Flanders (IWT Vlaanderen). Technical assistance by Kristine Piccart, Sofie Piepers and Lars Hulpio was appreciated.

\section{Author details}

${ }^{1}$ M-team and Mastitis and Milk Quality Research Unit, Department of Reproduction, Obstetrics and Herd Health, Faculty of Veterinary Medicine, Ghent University, Salisburylaan 133, Merelbeke, Belgium. ${ }^{2}$ Animal Genetics Laboratory, Department of Nutrition, Genetics, and Ethology, Faculty of Veterinary Medicine, Ghent University, Heidestraat 19, Merelbeke, Belgium.

Received: 25 February 2015 Accepted: 7 April 2015

Published online: 22 April 2015

\section{References}

1. Paape M, Mehrzad J, Zhao X, Detilleux J, Burvenich C. Defense of the bovine mammary gland by polymorphonuclear neutrophil leukocytes. J Mammary Gland Biol Neoplasia. 2002;7:109-21.

2. Barber MR, Yang TJ. Chemotactic activities in nonmastitic and mastitic mammary secretions: Presence of interleukin-8 in mastitic but not nonmastitic secretions. Clin Diagn Lab Immunol. 1998:5:82-6.

3. Rambeaud M, Clift R, Pighetti GM. Association of a bovine CXCR2 gene polymorphism with neutrophil survival and killing ability. Vet Immunol Immunopathol. 2006;111:231-8.

4. Verbeke J, Piepers S, Peelman U, Van Poucke M, De Vliegher S. Pathogen-group specific association between CXCR1 polymorphisms and subclinical mastitis in dairy heifers. J Dairy Res. 2012;79:341-51.

5. Pighetti GM, Kojima CJ, Wojakiewicz L, Rambeaud M. The bovine CXCR1 gene is highly polymorphic. Vet Immunol Immunopathol. 2012;145:464-70.

6. Verbeke J, Piepers S, Peelman L, Van Poucke M, De VLiegher S. Association of CXCR1 polymorphisms with apoptosis, necrosis and concentration of milk neutrophils in early lactating dairy heifers. Res Vet Sci. 2014;97:55-9.

7. National Mastitis Council. Laboratory Handbook on Bovine Mastitis. Madison, Wl: National Mastitis Counc. Inc; 1999.

8. Piessens V, Van Coillie E, Verbist B, Supre K, Braem G, Van Nuffel A, et al. Distribution of coagulase-negative Staphylococcus species from milk and environment of dairy cows differs between herds. J Dairy Sci. 2011;94:2933-44.

9. De Vliegher S, Opsomer G, Vanrolleghem A, Devriese LA, Sampimon OC, Sol J, et al. In vitro growth inhibition of major mastitis pathogens by Staphylococcus chromogenes originating from teat apices of dairy heifers. Vet Microbiol. 2004;101:215-21.

10. Untergasser A, Nijveen H, Rao X, Bisseling T, Geurts R, Leunissen JAM. Primer3Plus, an enhanced web interface to Primer3. Nucleic Acids Res. 2007;35:W71-4.

11. Zuker M. Mfold web server for nucleic acid folding and hybridization prediction. Nucleic Acids Res. 2003;31:3406-15.

12. Altschul SF, Gish W, Miller W, Myers EW, Lipman DJ. Basic Local Alignment Search Tool. J Mol Biol. 1990;215:403-10.

13. Goossens K, Van Poucke M, Van Soom A, Vandesompele J, Van Zeveren A, Peelman $L$. Selection of reference genes for quantitative real-time PCR in bovine preimplantation embryos. BMC Dev Biol. 2005;5L:27.

14. Stevens MGH, Peelman L, De Spiegeleer B, Pezeshki A, Van De Walle GR, Duchateau $L$, et al. Differential gene expression of the toll-like receptor-4 cascade and neutrophil function in early- and mid-lactating dairy cows. J Dairy Sci. 2011;94:1277-88.

15. Varshney N, Mohanty AK, Kumar S, Kaushik JK, Dang AK, Mukesh M, et al. Selection of suitable reference genes for quantitative gene expression studies in milk somatic cells of lactating cows (Bos indicus). J Dairy Sci. 2012;95:2935-45.

16. Andersen $C L$, Jensen $J L$, Orntoft TF. Normalization of real-time quantitative reverse transcription-PCR data: A model-based variance estimation approach to identify genes suited for normalization, applied to bladder and colon cancer data sets. Cancer Res. 2004;64:5245-50.

17. Mitterhuemer S, Petzl W, Krebs S, Mehne D, Klanner A, Wolf E, et al. Escherichia coli infection induces distinct local and systemic transcriptome responses in the mammary gland. BMC Genomics. 2010;11:138.
18. Blagitz MG, Souza FN, Batista CF, Diniz SA, Azevedo LF, Silva MX, et al. Flow cytometric analysis: Interdependence of healthy and infected udder quarters. J Dairy Sci. 2015;98:2401-8.

19. Jacobs AAA, Dijkstra J, Hendriks WH, van Baal J, van Vuuren AM. Comparison between stearoyl-CoA desaturase expression in milk somatic cells and in mammary tissue of lactating dairy cows. J Anim Physiol Anim Nutr. 2013;97:353-62.

20. Bustin SA, Benes V, Garson JA, Hellemans J, Huggett J, Kubista M, et al. The MIQE Guidelines: Minimum Information for Publication of Quantitative Real-Time PCR Experiments. Clin Chem. 2009;55:611-22.

21. Leyva-Baca I, Pighetti G, Karrow NA. Genotype-specific IL8RA gene expression in bovine neutrophils in response to Escherichia coli lipopolysaccharide challenge. Anim Genet. 2008;39:298-300.

22. Vandesompele J, De Preter K, Pattyn F, Poppe B, Van Roy N, et al. Accurate normalization of real-time quantitative RT-PCR data by geometric averaging of multiple internal control genes. Genome Biol 2002, 3:research0034. 1-0034.11.

23. Beecher C, Daly M, Ross RP, Flynn J, McCarthy TV, Giblin L. Characterization of the bovine innate immune response in milk somatic cells following intramammary infection with Streptococcus dysgalactiae subspecies dysgalactiae. J Dairy Sci. 2012;95:5720-9.

\section{Submit your next manuscript to BioMed Central and take full advantage of:}

- Convenient online submission

- Thorough peer review

- No space constraints or color figure charges

- Immediate publication on acceptance

- Inclusion in PubMed, CAS, Scopus and Google Scholar

- Research which is freely available for redistribution 